\title{
SMARTPHONE VIDEO RECORDING AS A LEARNING TOOL TO IMPROVE INDONESIAN EFL STUDENTS' SPEAKING PERFORMANCE
}

\author{
Dzakiah \\ Department of English Language Education, Faculty of Tarbiyah and Teachers Training, \\ State Institute for Islamic Studies Palu, Indonesia \\ E-mail: dzakiah@iainpalu.ac.id
}

\author{
Muhammad Azwar Assiddiq \\ English Language Education Study Program, Faculty of Teacher Training and Education, Khairun University, \\ Indonesia \\ E-mail: azwarassiddiq@unkhair.ac.id
}

Sri Hariati Mustari

Department of Government Science, Institute of Political Social Sciences 17-8-1945, Makassar, Indonesia

E-mail: srimustari@gmail.com

\begin{abstract}
APA Citation: Dzakiah, Assiddiq, M. A., \& Mustari, S. H. (2020). Smartphone video recording as a learning tool to improve Indonesian EFL students' speaking performance. Indonesian EFL Journal, 6(2), 157-164. doi: 10.25134/ieflj.v6i2.3384.
\end{abstract}

\begin{abstract}
This research attempts to reveal the effectiveness of using smartphone video recording as an English learning tool to improve the students' speaking performance and the students' interest in using the tool in speaking learning process. All participants were second-grade students of private boarding school in Makassar, Indonesia. This research was conducted through quasi experimental study design with two groups comprises of 25 students in the experimental group and 25 students in the control group. The instruments were speaking test to collect the data about the students' speaking performance and questionnaire to find out the students' interest. The data collections were then analyzed through descriptive and inferential statistics through SPSS Program Version 23.0. The result of data analysis showed that (1) using smartphone video recording was more effective than in-class monologue presentation to improve the students' performance in speaking. It is seen from the significance $t$ test result that reveals the significance value is lower than the significance level; $0.005<0.05$. Furthermore, in relation to the students' interest in using smartphone video recording to learn speaking and (2) it was found that the students' interest in using smartphone video recording was categorized as high.
\end{abstract}

Keywords: Smartphone video recording; speaking performance; interest.

\section{INTRODUCTION}

The progressive advancements of information and communication technology have impacted humans in many aspects of life (Williams 2011; Bosamia 2013; Romero-Ruiz et al. 2017). The role of technology in fulfilling needs, solving problems, and satisfying wants have been increased from time to time and it turns out to be a primary need of life. Mobile devices as the most developed technology are preferred for their mobilities and practicalities. Smartphone, the most sophisticated handheld device, becomes an emerging phenomenon in human life for its numerous advantages in extraordinary manners. More features and applications provided to facilitate human in a single handheld device has changed the way they learn, communicate and even live. Their attitudes to contents and various activities on the internet and electronic devices are very positive (Huang, Lin, and Chuang 2007).

These days, smartphones have become more accessible to younger consumers. Most, if not all students nowadays already have their smartphones in their pockets. Smartphones provide access to their needs to keep connected to people all over the world and prove their existence through social media by merely scrolling down fingers on the screen. More than that, they can see pictures, watch and create videos to be shared with their peers in their social network. The use of smartphone in the social area is imperative rather than a choice (Ali Dogan 2016). Spreading information and accessing sources of learning become easier but the other effects cannot be ignored. Consequently, the number of time students spends with their 
smartphone is excessive. They prefer spending them after school time to go online and chatting to reading their schoolbooks.

Teaching and learning processes must be dynamic and keep on adapting to the social changes in the students' environment (Darling, Linda, Harvey, Barron, and Osher, 2019). Teachers should be capable of adjusting the lesson to the students' preferences, needs, and habits. Considering the current state of the students regarding their attachment to smartphones, the researcher believes that this is better considered constructive instead of a timeconsuming activity. Smartphone integration into the learning process can be a potential tool in constructing knowledge and enhancing the students' skills (Hamdani 2013; Keengwe and Bhargava 2013; Sung, Chang, and Liu 2016). Vavuola (2004) suggested that the students' activities and the learning process should be integrated to help the students achieve the goals more easily. The tendency of the students to treat smartphone as a primary need and use it in their daily activities will become a great support to the process in achieving the goals of teaching and learning as long as the educators design the learning process well.

The feasibility of integrating smartphones into language learning activities which is widely known as Mobile Assisted Language Learning (MALL) has attracted many researchers worldwide to investigate it. This issue has become one of the most sophisticated fields of research, yet most of them focus on receptive skills such as listening comprehension (Azar and Nasiri 2014), reading comprehension (Hazaea and Alzubi 2016), and vocabulary (Liu 2016). Besides, most of the research subjects are undergraduate students. It is considered vital to investigate the effects of smartphone on the high school students considering the circumstances that the smartphone addiction these days has excessively influenced the students in junior high schools.

Taking into account that in-class learning process with limited hours and place can limit the students' language learning, MALL provides assistance in ubiquitous learning. Smartphone can be a source of learning anywhere and anytime both in formal and informal settings. Since language learning needs to be supported by some extra activities outside the classroom (Saran, Cagiltay, and Seferoglu 2008) and the case that the limited time they have in the classroom, bringing an outside-of-classroom activity is worth investigating.

The use of smartphone in the learning process has drawn a great deal of attention, particularly concerning language learning. Many researchers have conducted research related to the use of smartphone in the language learning process, such as Aamri and Suleiman 2011; Kétyi 2013; Gromik 2012; and Azar and Nasiri 2014.

Aamri and Suleiman (2011) investigated the current use and practices of smartphones in the English learning process. The subjects are the freshmen year students of Sultan Qaboos University. This paper concerned about the students' behavior, attitudes, and the problem they faced in utilizing smartphones in their educational setting. The result indicates that the students like to use them but the teachers do not recommend them considering the big distraction they will probably come up with. They suggested that the mobile phone is a blessing only if the students can handle it wisely. It is still needed to prove that despite the disadvantage, this device potentially can help in excessive ways in the educational field. The researcher came up with the implication to use mobile devices in the learning and educational process.

Kétyi (2013) researched the use of smartphones in language learning to 70 voluntary college students who learn German as a second language. From the result of the research, he concluded that if mobile devices can be integrated into the language teaching practice, the students will be able to gain valuable additional learning time outside of the classroom and this will improve the efficiency of their language learning.

Gromik (2012) in his research found through interviews, surveys, and observations that the students gained some improvements in the range of items spoken and they speak more words within the time allocated after producing 30 seconds video recordings within 14 weeks. The results indicated that students' oral performances are increased. The nine Japanese students also agreed that the smartphone video recording feature is interesting and useful to improve language learning.

Azar and Nasiri (2014) investigated the listening comprehension of L2 learners' attitudes toward the effectiveness of mobile-assisted language learning. The subjects were $70 \mathrm{EFL}$ learners of Zaban Amooz in Mahabad, Iran. The results of the research showed that the listening comprehension of the experimental group who 
received instruction using smartphone outperformed the control group.

Regardless of many researches completed in this field. The researchers were interested to conduct research about the use of smartphone video recording as an English learning tool to improve speaking performance. Hence, this present research aimed at finding out whether or not the use of smartphone video recording is effective to improve the speaking performance of the Indonesian EFL students and whether or not the Indonesian EFL students are interested in using smartphone video recording as a learning tool.

Ahmed El Hariry (2015) describes mobile learning as any form of learning that occurs by using a mobile device. It means that wireless handheld devices hold the most important role in assisting the students' learning process. The handheld devices make it possible for the learners in accessing any kind of resources to deepen their understanding of the classroom content. The portability and accessibility of mobile devices have been a great potential to assist students in gaining knowledge anytime and anywhere.

Mobile learning is any service or facility that contributes to the acquisition of knowledge regardless of time and location (Lehner and Nösekabel 2002). The devices to be utilized in the educational process are any kind of handheld mobile technologies such as laptops, Smartphones, tablets, iPods, etc. Using these mobile devices, the learners are able to access learning anytime and anywhere at their convenience (Gromik 2012). This enables the students to take control of their own learning. It is up to the learners to use the sources of information instantly or to save then retrieve it later. It's use of personal, portable devices that enable new ways of learning, emphasizing continuity or spontaneity of access and interaction across different contexts of use (Kukulska-Hulme and Shield 2008). Based on the previous explanation, it can be seen that the concept of mobility in mobile learning has three significant areas: mobility of technology, mobility of learning, and mobility of learners (Mohamed Osman M. El-Hussein and Johannes C. Cronje 2010).

Mobility of technology includes all mobile devices such as smartphones, digital cameras, handheld computers, or other mobile devices that are provided with wireless application protocol or Wi-Fi. These technologies deliver content and instruction through the internet that can enable the students to learn anywhere and anytime. Mobile technology also enables users to perform many different kinds of social-interactive functions including phone, SMS, email, etc.

Mobility of learning generates new modes of educational delivery, they are personalized, learner-centred, situated, collaborative, ubiquitous, and lifelong learning (Sharples, Taylor, and Vavoula 2005). The mobile learners can have very personal and unique experiences within the context they are situated. They can easily connect with each other for their own purpose and interest.

The mobility of learners is enhanced through mobile learning. The students take advantages of their flexible, accessible, and personalized learning activities to enhance their productivity and effectiveness. Mobile learners can develop sense of individuality, community, and iniquitousness in learning which might bring them the enjoyment of having a certain amount of freedom and independence. Mobile learning which is applied exclusively for language learning is called Mobile assisted language learning (MALL). Bezircilioğlu (2016) highlighted MALL, in broad terms, is the integration of mobile devices into the language learning process.

Researchers in the MALL consider Smartphone as an appropriate tool to be integrated in language learning for some reason. As a mobile device, they have an affinity with movement between indoors and outdoors, across formal and informal settings, allowing learners to lead at least some of the way (Kukulska-Hulme 2009), they are usually owned by the students themselves, at a relatively low-cost and they have been getting used to it (Johnson, L., Smith, R., Willis, H., Levine, A., and Haywood 2011). The teachers do not have to give extra assistance to teach them because they already familiar with the handheld device. Various features and applications in the latest Smartphones to support the students in enhancing their listening, reading, speaking, and writing are created. The effectiveness has been much investigated to prove that they possess the potential to be used in language learning. Kiernan and Aizawa (2004) found that the students' language acquisition is significantly enhanced through the application of Smartphones as tools in EFL classrooms. Many apps have the potential to be powerful resource creation tools, helping to support students beyond the classroom (Milliner 2015). 
Numerous features and applications have been explored to see the effectiveness of the Smartphone to be integrated into language learning. Much of the research conducted with Smartphones focuses on vocabulary, reading, and listening skills (Gromik 2012; Bozdoğan 2015). However, some researchers have also investigated the use of Smartphones as tools in speaking classes such as Gromik (2012) and Shakarami, Khajehei, and Hajhashemi (2014). There are two technological tools in Smartphones which can be used for speaking. They are video recording program and audio recording program (Bozdoğan 2015). Both have been investigated by different researchers to be applied in higher education settings and are proved to be effective.

The regularity of the students using the video recording feature encourages them to become more conscious about their speaking competence. They hold the role as a producer and also an evaluator of their oral output (Gromik 2012). It promoted students' autonomy by moving students away from dependence on teachers and towards independence in managing one's learning by giving them mobile and independent access to materials and sources. The regularity of the task also engaged the students to recollect their prior knowledge of the target language and to develop new vocabularies to express their opinions.

It was envisaged that the activity will foster the learners' concentration which will cause them to spend more time practicing oral skills. It is supposed to encourage the students to improve their learning of the target language.

Smartphone-based learning, due to the many applications and features available that can be used for recording and playing multimedia contents, also allows its owner to become an active producer of content (Gromik 2012). Shakarami et al. (2014) showed in his research that Smartphones can serve as practical devices to empower EFL learners to upgrade their communicative skills. The students can greatly benefit for instance having a recorder on their Smartphones. A recorder allows the teacher to record lesson instructions, create authentic listening texts, record speaking activities, and, ask students to create audio content (e.g. retelling stories).

During in-class speaking tasks, students can record themselves to evaluate pronunciation or prepare for a speaking task. Pipe introduced an effective way to generate peer feedback when he introduced an activity whereby students record a short conversation and then share it with another team who would transcribe and critique the conversation (Milliner 2015).

Liu (2016) suggest teaching by using wireless and mobile technologies following these steps: class preparation, introducing guidelines, designing the topic and planning projects, implementing group projects, presentation, and evaluation, revising, sharing, and grading. The teachers need to ensure that mobile technologies or in this case Smartphone is well functioned as a learning tool by designing the project well.

\section{METHOD}

This present research applied an experimental method that focuses on quasi-experimental design. The participants were chosen by using a cluster sampling technique and distributed into two groups, namely experimental group and control group. Each of the groups consisted of 25 students. All participants were second-grade students of private boarding school in Makassar, Indonesia and ranged between 16 and 18 years in age. They formed up a representative sample of Indonesian EFL students.

This research employed two kinds of instruments, they are the speaking test and questionnaire. The speaking test was used to find out the Indonesian EFL students' speaking performance. It was distributed in the pretest and posttest. The topic options of speaking in the pretest were similar to that of the posttest. The participants were asked to perform one of the three topics of monologue provided by the researcher. The questionnaire was applied to take the data related to the students' interest in the use of Smartphone video recording as a tool in speaking practice. The questionnaire was administered after the submission of the last video recording. It covers 20 items, 10 positive statements and 10 negative statements with five scales: strongly disagree (1), disagree (2), neutral (3), agree (4), and strongly agree (5). The data collected then were analyzed using Statistical Product and Service Solution (SPSS) Program version 23.0.

In the experimental group, the students created videos related to the activities they did and the feeling they felt in the previous day. They used their smartphone in the video production and were expected to submit the video through Bluetooth, WhatsApp, or Messenger before the next meeting was held. This activity was organized to be done twice a week in 6 weeks. There were twelve videos that each of the students made at the end of the treatment. In the 
control group, the researcher applied the conventional method that the teacher frequently used in the speaking learning process that was in class monologue presentation in which each student was asked to speak in front of the classroom about his/her past experiences.

\section{RESULTS AND DISCUSSION Students' speaking performance}

\begin{tabular}{ccc} 
Table 1. The students' & mean score of speaking in & pretest and post-test \\
\hline Group & Pretest & Post-test \\
\hline Experimental & 41.44 & 63.56 \\
Control & 41.32 & 53.16 \\
Difference & & 10.4 \\
\hline
\end{tabular}

After conducting the pretest, treatment, and posttest for both experimental and control group, comparing the post-test results of both groups to prove the significant improvement in the students' speaking performance of experimental group was done. It can be seen in table 1 that the pretest mean score of the students is not significantly different which emphasize that the prior knowledge of both groups were similar. However, the result shows that the mean score of the students' post-test both groups increased after the treatment but the experimental groups got higher mean score than the control group by 10.4 points. The result of the posttest indicated that the use of cell phone video recording gave significant progress toward the students' speaking performance.

Next, after examining the data through normality test to determine whether the data had to be tested through parametric or nonparametric, the researcher analyzed the t-test for independent sample test using SPPS version 23.0. It was to ensure a significant difference between students' speaking performance in the experimental class and the control class before and after treatments was conducted. The output of SPSS can be seen in the Table 2.

Table 2. The p-value of t-test

\begin{tabular}{cccl}
\hline Variables & P-value & $(\alpha)$ & \multicolumn{1}{c}{ Remarks } \\
\hline Pretest & 0.975 & 0.05 & Not Significantly Different \\
Posttest & 0.005 & 0.05 & Significantly Different \\
\hline
\end{tabular}

As reported in Table 2, it was found that the p-value of the pretest in the authentic and pedagogic group was 0.975 , while the $p$-value of the posttest was 0.00. It means that the p-value of pretest in both groups was greater than the level of significance which was $0.05(0.975<0.05)$. Consequently, the null hypothesis $\left(\mathrm{H}_{0}\right)$ was accepted and the alternative hypothesis $\left(\mathrm{H}_{1}\right)$ was rejected. In other words, there were no significant differences between the speaking performance of participants in the experimental and control group before the treatments were applied. Meanwhile, based on participants' performance on the posttest both experimental and control group, it found that $\mathrm{p}$-value was 0.005 . It was smaller than the level of significance which was $0.05(0.005<0.05)$. This proved that the alternative hypothesis $\left(\mathrm{H}_{1}\right)$ was accepted and the null hypothesis $\left(\mathrm{H}_{0}\right)$ was rejected. Therefore, it can be summarized that the implementation of cell phone video recording improved the students' speaking performance or the implementation of cell phone video recording was more effective to improve the students' speaking performance than in-class monologue presentation, the conventional way.

Furthermore, the detailed information about the students' speaking performance based on the speaking components; accuracy, fluency, and comprehensibility, before and after conducting the treatment are also included. Without a doubt, the implication of using cell phone video recording as a media in helping the students to be a better speaker is also clearly seen from the three components below.

Table 3. Students' mean score of speaking based on the components of speaking

\begin{tabular}{lcccc}
\hline \multirow{2}{*}{ Speaking Elements } & \multicolumn{2}{c}{ Control Group } & \multicolumn{2}{c}{ Experimental Group } \\
\cline { 2 - 5 } & Pretest & Post-test & Pretest & Post-test \\
\hline Accuracy & 36.67 & 46.00 & 36.67 & 57.33 \\
Fluency & 40.00 & 56.00 & 42.00 & 64.00 \\
Comprehensibility & 45.33 & 57.33 & 47.33 & 69.33 \\
\hline
\end{tabular}




\section{Accuracy}

Referring to the findings in Table 3, the students' average score of both groups in terms of accuracy is 36.67 , which is categorized as fair means that the students of the two groups possess quite low speaking performance before learning speaking using the techniques that was applied by the researcher. In other words, the pronunciation, grammar, and vocabulary of their speaking were far from what the literature says as acceptable. In fact, most of the students spoke without acceptable pronunciation, correct grammar and vocabulary. They needed to be trained repeatedly and regularly. However, after treatment, the students of the experimental group who learned using the cell phone video recording show a significant improvement in their speaking performance.

In addition, they used appropriate tense that usually occurs in telling experiences such as past tense, and pronunciation became better than before having the treatment. Therefore, the students' performance in speaking in term of accuracy is classified as fairly good (57.33). On the other side, the students' speaking ability by accuracy of the control group was also improved to fairly good, from 36.67 to 46.00 . In other words, there is an improvement in their speaking performance after learning through conventional method despite the fact that it was not as well as the experimental group.

From these findings, it can be concluded that using cell phone video recording as a tool in learning significantly improved the students' speaking performance in terms of accuracy in the sense that cell phone video recording can help the students to speak more accurately (less mother tongue influence, grammatical and lexical errors). Therefore, it can be inferred that the students' speaking performance at the experimental group by accuracy was better than the control group after learning using cell phone video recording.

\section{Fluency}

Based on the result of the students' speaking performance in terms of fluency at pretest or before given the treatment, the score shows that the students have quite low competence in speaking fluently. However, from the posttest speaking result, it was found that most of the students in the experimental group are able to speak more smoothly and fluently without making many unnatural pauses, fragmentary and halting delivery after learning using cell phone video recording. The mean score at posttest appeared to be much higher than at pretest from fairly good (42.00) to good (64.00).

Unlike the students' speaking performance by fluency at the experimental group, the students' speaking performance of the control group was still at the level of fairly good after given the treatment which means that there is no significant improvement on their speaking performance. Based on this statement, it can be concluded that the students' speaking performance in terms of fluency of the experimental group after using cell phone video recording was better than the control group's fluency that used conventional method.

\section{Comprehensibility}

In terms of comprehensibility, the researcher found that the students' performance comprehensibility at pretest was categorized as fairly good for both experimental and control group. As the impact of the students spoke unclear, halting and fragmentary, it was quite hard to comprehend what they intended to say. However, the result of posttest speaking performance by comprehensibility seems better than at pretest. Based on the posttest speaking result, it was found that the students in experimental group are able to convey their main ideas more clearly after learning through the use of cell phone video recording. Their competence in comprehensibility was improved to be good with mean score 69.33 .

Unlike the students' performance in speaking by comprehensibility at the experimental group, the students' performance of the experimental group in speaking in terms of comprehensibility was still at fairly good category. This means that there is no significant improvement at the students' speaking performance of the control group compared to the experimental group in terms of comprehensibility. After comparing the two groups' speaking performance, it can be assumed that the students' speaking performance in terms of comprehensibility aspect of the experimental group treated through the use of cell phone video recording was better than the students' speaking performance in terms of comprehensibility aspect of the control group treated by conventional method.

There are two main reasons why the control group had also improvements after the treatment although it was not as significant as the experimental group. They are: (1) the students in control group were given six meetings of treatment as in the experimental group, and; (2) the control group was treated based on the teacher-based technique and her technique forced, 
facilitated and gave chance to the students to speak and to express their ideas in every meeting.

Certainly, the statistical result above tells us that the speaking performance of Indonesian EFL students significantly improved or was affected by the use of cell phone video recording as a tool in learning to tell experiences. In addition, the students who learned by using cell phone video recording seem to be more free to tell their experiences without feeling shy or afraid of losing face in front of their friends. Hence, the students can train themselves and develop their speaking performance without feeling worry about what will their friends say. The cell phone gives them the opportunity to be actively engaged in the learning process. It made the process of learning becoming more productive. This condition is in line with Bezircilioğlu (2016) who states in his article that the integration of cell phone into the learning process makes the process more productive. All of the students participated actively during the process of teaching and learning.

The result of this research seems to be consistent with the result of a case study research done by Gromik (2012) who proved that cell phone video recording could improve the students' speaking performance. The students who learned speaking through cell phone video creation were able to increase the number of words they spoke in one monologue. They were able to consistently improve their word output in a particular time.

Another research finding which also supports this research finding is a research conducted by Shakarami et al. (2014) who investigated about the use of cell phone audio recording to improve speaking performance. The finding showed that the feature lent help to students to improve their verbal performance to some extent. The more the students have access to and practice with mobile phones as a language learning device, the more they will get benefit and enjoy the learning process to enhance their language learning. Although some students found it challenging at first, the recording activity turned to be interesting and enjoyable at last and contribute positively to the students' speaking performance.

\section{Students' interest}

Regarding to the finding about the interest of the students in experimental group, the researcher analyzed that the students were interested in using cell phone video recording in learning speaking. The result shows that 2 students gave very high respond, 14 students gave high respond, 9 students gave moderate respond and none gave low and very low respond towards the implementation of cell phone video recording. The finding is also supported by the mean score of the students' interest that shows the students' interest is categorized as high interest. Therefore, it can be inferred that the implementation of cell phone video recording is interesting for the students to be used in learning speaking.

The students' interest level in learning through cell phone video recording seems to be in line with the students' speaking performance in the sense that the students' speaking performance improved after learning through cell phone video recording and the students had high interest to learn. Based on the finding it is found that students who are interested tend to have high performance in their speaking and vice versa. On the other hand, we can say that the higher the students' interest, the better the students' speaking performance.

Speaking performance and interest have strong relationship. The Pearson's $r$ for correlation between students' students' speaking performance and interest is 0.978 with the sig. (2 tailed) value is less than 0.05 and the positive value indicates that there is strong relationship between interest and speaking performance variables. When the interest of students increases, the students' speaking performances also increase. Overall, there was a strong significant and positive correlation between interest and speaking performance. Increases in interest were correlated with increases in the rating of speaking performance.

As assuming in this research, the students' interest was considered as output because they were expected to have higher interest through using cell phone video recording in learning speaking. It can be seen that interest has an important role in learning process. In order to have the students learn well, the interesting learning environment should be created. This means that cell phone video recording as a learning tool that was able to interest the students is a good to be used tool in improving the students' speaking performance.

\section{CONCLUSION}

The students' speaking performance was significantly improved in terms of accuracy, fluency, and comprehensibility after learning to speak using cell phone video recording especially in telling past events and activities. The video recording feature of the cell phone is also 
considered interesting for the students to be used as an English learning tool. Furthermore, the result also showed that there is a high and positive correlation between the students' speaking performance and their interests in using cell phone video recording as a learning tool. It means that the higher the students' interest the better their speaking performance. The results of this research are expected to help both students and teacher in the teaching learning process. Fostering the use of cell phone video recording, the teacher should be able to organize it well in order to make the entire steps of learning run well and the students can achieve the learning objectives.

\section{REFFERENCES}

Aamri, Al, \& Suleiman, K. (2011). The use of mobile phones in learning English language by Sultan Qaboos university students: practices, attitudes and challenges. Canadian Journal on Scientific \& Industrial Research, 2(3), 143-52.

Azar, A. S. \& Nasiri, H. 2014. "Learners' attitudes toward the effectiveness of mobile assisted language learning (MALL) in L2 listening comprehension." Procedia - Social and Behavioral Sciences 98:1836-43.

Bezircilioğlu, S. (2016). Mobile assisted language learning experiences. Journal of Educational and Instructional Studies in the World, 6(1):2146-7463.

Bosamia, M. (2013). Positive and negative impacts of information and communication technology in our everyday life. Conference Paper (June).

Bozdoğan, D. (2015). MALL revisited: Current trends and pedagogical implications." Procedia - Social and Behavioral Sciences 195:932-39.

El Hariry, N. A. (2015). Mobile phones as useful language learning tools. European Scientific Journal, 11(16): 298-317.

El-Hussein, M. O. S \& Cronje, J. C. (2010). Defining mobile learning in the higher education landscape Mohamed. Educational Technology \& Society 13(3):12-21.

Dogan, A. \& Akbarov, A. (2016). Teachers' attitudes toward the usage of mobile devices in EFL classroom. European Journal of Educational Research, 5(1):11-17.

Gromik, N. A. (2012). Cell phone video recording feature as a language learning tool: A case study. Computers and Education, 58(1): 223-30.

Hamdani, D. S. A. (2013). Mobile learning: A good practice. Procedia - Social and Behavioral Sciences 103:665-74.

Hazaea, A. \& Alzubi, A. A. (2016). The effectiveness of using mobile on EFL learners' reading practices in Najran University. English Language Teaching, 9(6): 8-32

Huang, J. H., Lin, Y. R. \& Chuang, S. T. (2007). Elucidating user behavior of mobile learning: A perspective of the extended technology acceptance model. Electronic Library, 25(5):585-98.

Hulme, A. K. (2009). "Will mobile learning change language learning?" ReCALL 21(2):157-65.

Johnson, L., Smith, R., Willis, H., Levine, A., and Haywood, K. 2011. The 2011 horizon report.

Keengwe, J, \& Bhargava, M. (2013). Mobile learning and integration of mobile technologies in education. Education and Information Technologies. 19(4):737-46.

Kétyi, A. (2013). Using smart phones in language learning - A pilot study to turn CALL into MALL." Eurocall (2013): 129-34.

Kiernan, P. J. \& Aizawa, K. (2004). Cell phones in task based learning are cell phones useful language learning tools?" ReCALL 16(1): 71-84.

Lehner, F. \& Nösekabel, H. (2002). The role of mobile devices in e-learning first experiences with a wireless e-learning environment. Proceedings IEEE International Workshop on Wireless and Mobile Technologies in Education, WMTE 2002, 103-6.

Liu, P. L. (2016). Mobile English vocabulary learning based on concept-mapping strategy. Language Learning and Technology, 20(3):128-41.

Milliner, B. (2015). Using smartphones in the language classroom: Making the most of core smartphone apps.” Accents Asia, 1(8): 9-11.

Romero-Ruiz, K, Sánchez, L. E., Plata, J. P., Giraldo, S. V. Cardona, M. A., Avendaño, C. H., Arias, A. C. \& Piedrahita. L. B. (2017). "Information and communication technologies impact on family relationship." Procedia - Social and Behavioral Sciences 237(June 2016):30-37.

Saran, M. Cagiltay, K. \& Seferoglu, G. (2008). Use of mobile phones in language learning: developing effective instructional materials. Proceedings 5th IEEE International Conference on Wireless, Mobile, and Ubiquitous Technologies in Education, WMUTE 2008 39-43.

Shakarami, A., Khajehei, H. \& Hajhashemi, K. (2014). Tech-assisted language learning tasks in an EFL setting: Use of hand phone recording feature. International Journal of Applied Linguistics and English Literature, 3(5):100103.

Sharples, M., Taylor, J. \& Vavoula, G. (2005). Towards a theory of mobile learning. Proceedings of MLearn 2005 (January).

Sung, Y. T., Chang, K. E. \& Liu, T. C. (2016). The effects of integrating mobile devices with teaching and learning on students' learning performance: A meta-analysis and research synthesis." Computers and Education, 94. 25275.

Williams, E. (2011). Environmental effects of information and communications technologies. Nature, 479(7373): 354-58. 